RESEARCH NOTE

\title{
A DIAGNOSTIC ASSAY BASED ON VARIABLE INTERGENIC REGION DISTINGUISHES BETWEEN LEISHMANIA DONOVANI AND LEISHMANIA INFANTUM
}

\author{
Eva Chocholová ${ }^{1,2,3}$, Milan Jirkư ${ }^{1}$ and Julius Lukeš ${ }^{1}$ \\ ${ }^{1}$ Institute of Parasitology, Biology Centre, Academy of Sciences of the Czech Republic, Branišovská 31, 37005 České \\ Budějovice, Czech Republic; \\ ${ }^{2}$ Present address: Centre for Cellular and Molecular Neurobiology, University of Liege, B-4000 Liege, Belgium; \\ ${ }^{3}$ Previous name: Eva Zemanová
}

Abstract. We have developed a PCR assay that in a single reaction distinguishes between Leishmania infantum and Leishmania donovani strains on the basis of different size of the amplicon. The targeted intergenic region between putative biopterin transporter and nucleotide binding protein on chromosome 35 is highly variable, species-specific and can be amplified from clinical samples. Based on the assay, five tested Leishmania archibaldi and L. infantum strains from the Sudan and Ethiopia clearly belong to $L$. donovani, which is in accordance with a recent multifactorial analysis of these strains. The nucleotide sequence reported in this paper has been submitted to the GenBank ${ }^{\mathrm{TM}}$ with accession number EU068004.

Kinetoplastid flagellates of the genus Leishmania Ross, 1903 are the causative agents of leishmaniases, a group of diseases that are estimated to affect 12 million people, with 350 million people at risk and the death toll of about 57,000 worldwide annually (Desjeux 2004). The clinical symptoms range from asymptomatic or mild cutaneous leishmaniasis to severe mucocutaneous and visceral forms of the disease. In the Old World, cutaneous form is mainly caused by Leishmania major, L. tropica and L. infantum, whereas $L$. donovani and $L$. infantum are the main species responsible for visceral leishmaniasis. Since pathology is generally species-specific, fast and unambiguous species identification is necessary for the choice of proper therapy and prognosis of the clinical outcome.

Until the 1990s, diagnosis of these parasites was based on the microscopic detection of amastigotes in clinical samples and/or enzymatic characterisation of promastigotes obtained in culture. Only the latter method was able to distinguish among the Leishmania species, yet it is tedious, time-consuming and requires specialised equipment and expertise. Thus, the requirement for simple, rapid, specific and sensitive diagnostic methods for leishmaniases is obvious. In the last decade, the potential to meet these criteria was demonstrated for PCRbased methods amplifying kinetoplast DNA minicircles (Noyes et al. 1998), ribosomal intergenic regions (El Tai et al. 2001), gp63 gene (Dujardin et al. 2002), glucose-6-phosphate dehydrogenase gene (Castilho et al. 2003) and the miniexon sequence (Marfurt et al. 2003), to name the most widely used DNA targets. Amplicons usually contain single nucleotide polymorphisms or short regions characteristic for a given species or a group of strains, and provide sequence information valuable for species identification and phylogenetic analysis. However, since for almost all clinical laboratories in

Address for correspondence: J. Lukeš, Institute of Parasitology, Biology Centre, Academy of Sciences of the Czech Republic, Branišovská 31, 37005 České Budějovice, Czech Republic. Phone: ++420 387775 416; Fax: ++420 385310388 ;

E-mail:jula@paru.cas.cz the endemic countries routine sequencing is not available, usually the amplicons must be digested with selected restriction enzymes to identify species-specific sites (Schönian et al. 2003, Botilde et al. 2006). In order to determine the Leishmania species by PCR assays yielding a single speciesspecific product, one has to run several reactions with different primers and a number of controls (El Tai et al. 2001, Dujardin et al. 2002, Jirků et al. 2006). Elimination of these additional steps would streamline PCR-based diagnosis, make it cheaper, less time-consuming and more user-friendly. Eventually, it would also strengthen its position among diagnostic approaches towards leishmaniases in the community of clinicians. A novel assay fulfilling such requirements for two Leishmania species is introduced in this work.

In an attempt to find species-specific regions, we performed a detailed in silico search in the available sequence data. Such data mining allowed us to identify a $1.8 \mathrm{~kb}$ long intergenic region on chromosome 35 of the Friedlin strain of L. major, flanked by genes encoding putative biopterin transporter and nucleotide-binding proteins (L25643) (Ivens et al. 2005), in which $L$. infantum substantially differs from $L$. $m a-$ jor. Assuming that it may be a highly variable region, the 3' end of the former gene was used to design the forward primer TGAAGCGGGACAGCTAGC (position 2003479-2003496), while the reverse primer TCTGCCGTGCTATTTAG covers the 5' part of the latter gene (position 2005292-2005308). About $10 \mathrm{ng}$ of DNA from cultured promastigotes (Table 1), or an undetermined but much lower amount of DNA from amastigotes in clinical samples (Table 2), 10 pmol of each primer, reaction buffer $(100 \mathrm{mM}$ Tris- $\mathrm{HCl}, \mathrm{pH} 8.8 ; 500 \mathrm{mM}$ $\mathrm{KCl} ; 1 \%$ Triton $\mathrm{X}-100 ; 15 \mathrm{mM} \mathrm{MgCl} 2), 0.25 \mathrm{mM}$ dNTPs and $0.5 \mathrm{U} \mathrm{Taq}$ polymerase (Top-Bio, Prague) were processed in an Eppendorf Mastercycle through 30 cycles consisting of $60 \mathrm{~s}$ at $95^{\circ} \mathrm{C}, 60 \mathrm{~s}$ at $58^{\circ} \mathrm{C}$ and $90 \mathrm{~s}$ at $72^{\circ} \mathrm{C}$. Amplicons were separated in $1 \%$ agarose gel at $80 \mathrm{~V}$ in $0.5 \times$ TBE buffer in the presence of ethidium bromide and visualised under UV light. Selected amplicons were cloned and sequenced.

Based on the $L$. major genome sequence, the PCR product was predicted to be $1.8 \mathrm{~kb}$ long. Indeed, a single product of this size was obtained from all eight African strains tested, regardless of their current species affiliation (see below), and from $L$. donovani originating from India (four strains) and Saudi Arabia (two strains) and, as expected, from L. major (data not shown) (Table 1) (Fig. 1). However, all 21 assayed L. infantum strains consistently gave a strong $\sim 1.4 \mathrm{~kb}$ long amplicon (Fig. 2), whereas no product was obtained with $L$. tropica, $L$. aethiopica, L. arabica, L. turanica and L. gerbilli (data not shown). Thus, the PCR reaction was able to distinguish between $L$. infantum and $L$. donovani by amplifying a product of species-specific size (Figs. 1, 2). 
Table 1. Strains of Leishmania spp. used in this study in the form of DNA obtained from cultured promastigotes.

\begin{tabular}{|c|c|c|c|c|c|c|}
\hline Species $^{\mathrm{a}}$ & Lab code & WHO code & Zymodeme $^{\mathrm{c}}$ & Origin & $\begin{array}{l}\text { Type of infection } \\
\text { or Host }\end{array}$ & $\begin{array}{l}\text { Size of amplicon } \\
\text { in bp }\end{array}$ \\
\hline \multirow[t]{21}{*}{ L. infantum } & INF-01 & MHOM/FR/1978/LEM75 & MON 1 & France & Visceral & 1486 \\
\hline & INF-02 & MHOM/FR/1995/LPN114 & MON 1 & France & Visceral & 1486 \\
\hline & INF-03 & MHOM/1993/PM1 & MON 1 & Spain & Visceral & 1486 \\
\hline & INF-0 $4^{*}$ & MHOM/FR/1997/LSL29 & MON 1 & France & Cutaneous & 1486 \\
\hline & INF-05 & MHOM/ES/1986/BCN16 & MON 1 & Spain & Cutaneous & 1486 \\
\hline & INF-06 & MHOM/PT/2000/IMT260 & MON 1 & Portugal & Cutaneous & 1486 \\
\hline & INF-07 & MHOM/FR/1996/LEM3249 & MON 29 & France & Cutaneous & 1486 \\
\hline & INF- $08^{*}$ & MHOM/ES/1991/LEM2298 & MON 183 & Spain & Visceral & 1486 \\
\hline & INF-14 & MHOM/FR/1980/LEM189 & MON 11 & France & Visceral & 1486 \\
\hline & INF-15* & MHOM/MT/1985/BUCK & MON 78 & Malta & Visceral & 1486 \\
\hline & INF-19 & MHOM/ES/88/LLM175 & MON 198 & Spain & Visceral & 1486 \\
\hline & INF-20 & MHOM/ES/92/LLM373 & MON 199 & Spain & Visceral & 1486 \\
\hline & INF- $21^{*}$ & MHOM/IT/94/ISS1036 & MON 228 & Italy & Visceral & 1486 \\
\hline & INF-22 & MHOM/IT/93/ISS800 & MON 188 & Italy & Visceral & 1486 \\
\hline & INF-26* & MHOM/GR/2001/GH6 & MON 98 & Greece & Visceral & 1486 \\
\hline & INF-27 & MCAN/GR/2001/GD8 & MON 98 & Greece & Visceral & 1486 \\
\hline & INF-28 & MHOM/GR/2003/GH15 & MON 98 & Greece & Visceral & 1486 \\
\hline & INF-33 & MHOM/GR/2003/GH16 & MON 98 & Greece & Visceral & 1486 \\
\hline & INF-34 & MHOM/GR/2003/GH18 & MON 98 & Greece & Visceral & 1486 \\
\hline & INF-35 & MHOM/GR/2003/GH20 & MON 98 & Greece & Visceral & 1486 \\
\hline & INF-36 & MHOM/GR/2004/GD17 & MON 98 & Greece & Visceral & 1486 \\
\hline \multirow[t]{3}{*}{ L. archibaldi } & $\mathrm{ARC}-11^{*}$ & MHOM/ET/1972/GEBRE 1 & MON 82 & Ethiopia & Visceral & 1880 \\
\hline & $\mathrm{ARC}-24^{*}$ & MHOM/SD/97/LEM3429 & MON 257 & Sudan & Visceral & 1880 \\
\hline & ARC-25 & MHOM/SD/97/LEM3463 & MON 258 & Sudan & Visceral & 1880 \\
\hline \multirow[t]{9}{*}{ L. donovani } & DON-09 & MHOM/IN/0000/DEVI & MON 2 & India & Visceral & 1880 \\
\hline & DON-10* & MHOM/IN/1996/THAK35 & MON 2 & India & Visceral & 1880 \\
\hline & DON-12 & MHOM/SD/1982/GILANI & MON 30 & Sudan & Visceral & 1880 \\
\hline & DON-13* & MHOM/ET/0000/HUSSEN & LON 42 & Ethiopia & Visceral & 1880 \\
\hline & DON-16 & MHOM/IN/54/SC23 & MON 38 & India & Visceral & 1880 \\
\hline & DON-17* & MCAN/SD/2000/LEM3946 & MON 274 & Sudan & Visceral & 1880 \\
\hline & DON-29 & MHOM/IN/80/DD8 & MON 2 & India & Visceral & 1880 \\
\hline & DON-31 & MHOM/SA/81/KA-Jeddah & LON 42 & Saudi Arabia & Visceral & 1880 \\
\hline & DON-32* & MHOM/SA/87/VL29 & LON 42 & Saudi Arabia & Visceral & 1880 \\
\hline L. infantum & INF-18* & $\mathrm{MHOM} / \mathrm{SD} / 62 / 3 \mathrm{~S}$ & MON 81 & Sudan & Visceral & 1880 \\
\hline in Africa & INF-23* & MHOM/SD/97/LEM3472 & MON 267 & Sudan & Visceral & 1880 \\
\hline L. tropica & TRO & MHOM/SU/74/K 27 & MON 60 & Former Soviet Union & $?$ & - \\
\hline L. aethiopica & AET & MHOM/ET/72/L100 & MON 14 & Ethiopia & $\begin{array}{l}\text { Phlebotomus } \\
\text { arabicus }\end{array}$ & - \\
\hline L. arabica & ARA & MPSA/SA/83/JISH220 & MON 99 & Saudi Arabia & Psammomys obesus & - \\
\hline L. turanica & TUR & MRHO/SU/83/MARZ-051 & $?$ & Former Soviet Union & Rhombomys opimus & - \\
\hline L. gerbilli & GER & $\mathrm{MRHO} / \mathrm{CN} / 60 /$ Gerbilli & $?$ & China & R. opimus & - \\
\hline
\end{tabular}

${ }^{a}$ Strain identification according to isoenzyme analysis; ${ }^{b} \mathrm{WHO}$ reference strain; ${ }^{\mathrm{c}} \mathrm{zymodemes}$ are indicated as typed by the reference laboratory, Montpellier (MON) or London (LON); ${ }^{*}$ strains used for Figs. 1 and 2.

Table 2. Clinical samples of Leishmania infantum and L. donovani used in this study.

\begin{tabular}{|c|c|c|c|c|c|c|}
\hline $\begin{array}{l}\text { Clinical } \\
\text { samples }\end{array}$ & Code & Zymodeme & Origin & Type of infection & Sample & $\begin{array}{l}\text { Size of amplicon } \\
\text { in bp }\end{array}$ \\
\hline \multirow{9}{*}{ L. infantum } & & & & & Human (Bone Marrow) & \\
\hline & L-984 & MON 1 & Spain - Madrid & & -liver transplantant & 1486 \\
\hline & L-1122 & MON 1 & Spain - Mallorca & $\begin{array}{l}\text { Visceral } \\
\text { (HIV+, Relapse) }\end{array}$ & Human (Bone Marrow) & 1486 \\
\hline & L-1149 & MON 1 & Spain - Ibiza & & Canine (Lymph Node) & 1486 \\
\hline & $\mathrm{I}-288$ & MON 1 & Portugal - Alto Douro & Visceral (HIV-) & Human (Bone Marrow) & 1486 \\
\hline & $\mathrm{I}-337$ & MON 1 & Portugal - Alto Douro & Cutaneous (HIV-) & Human (lesions) & 1486 \\
\hline & $\mathrm{I}-170$ & MON 1 & Portugal - Alto Douro & & Phlebotomus & 1486 \\
\hline & $\mathrm{I}-300$ & MON 1 & Portugal - Setubal & & Canine (Bone Marrow) & 1486 \\
\hline & $\mathrm{I}-238$ & MON 1 & Portugal - Lisboa & Visceral (HIV+) & Human (Bone Marrow) & 1486 \\
\hline L. donovani & $\begin{array}{l}\text { Don J-Q } \\
\text { (8 samples) }\end{array}$ & $?$ & Nepal (Siraha) & Visceral & Human (Bone Marrow) & 1880 \\
\hline
\end{tabular}

Next, using the amplification primers we sequenced three $L$. infantum, two L. donovani and one $L$. archibaldi amplicons (data not shown). The alignment of obtained sequences showed that, as expected, the $1.8 \mathrm{~kb}$ long sequence of the Sudanese strains covers the intergenic region. Unexpectedly however, in the case of $L$. infantum, the $1.4 \mathrm{~kb}$ long PCR product is flanked on both ends by the forward primer that anneals to the putative integral membrane protein and missanneals to the intergenic region (position 1469-1486). In the overlapping part, the sequence is species-specific with several 


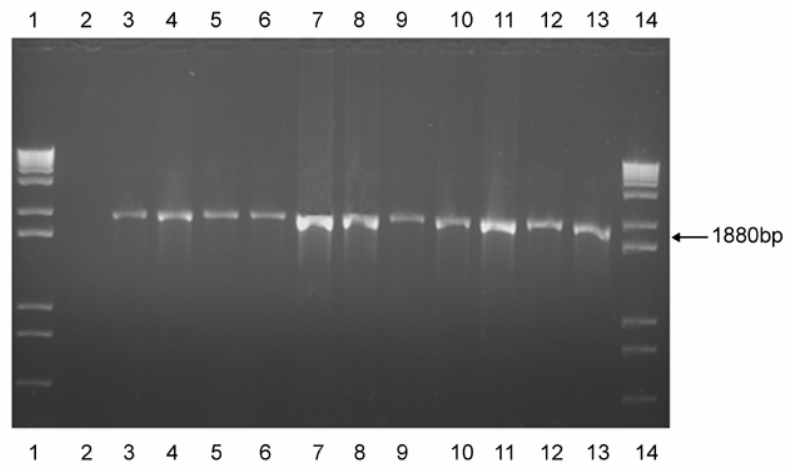

Fig. 1. Species-specificity of the PCR assay shown with a set of Leishmania donovani. DNA was obtained from cultured procyclics (strains DON-17, DON-13, DON-10 and DON-32) (lanes 3-6), clinical samples of $L$. donovani from Nepal (see Table 2) (lanes 7-9), cultured procyclics of Sudanese and Ethiopian " $L$. archibaldi" (strains ARC-24 and ARC-11) (lanes 10 and 11) and Sudanese "L. infantum" (strains INF-18 and INF-23) (lanes 12 and 13) (see text for details on species assignment). Flagellate-free human blood was used as a negative control (lane 2). $1 \mathrm{~kb}$ ladder DNA size marker (GibcoBRL) (lanes 1 and 14). The size of diagnostic PCR product is indicated.

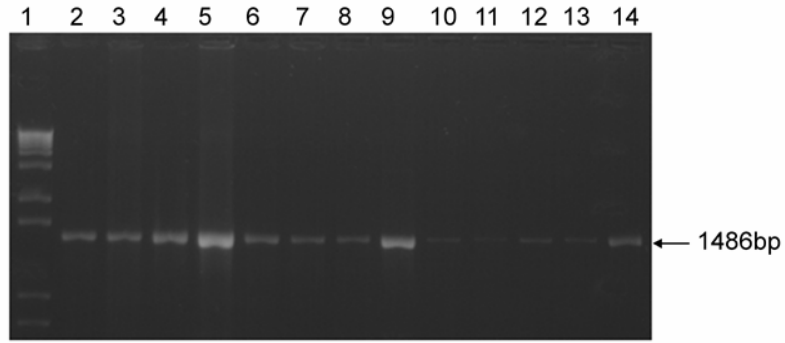

Fig. 2. Species-specificity of the PCR assay shown with a set of Leishmania infantum. DNA was obtained from cultured procyclics (INF-08, INF-21, INF-04, INF-35 and INF-15) (lanes 2-6), and clinical samples with previous diagnosis of $L$. infantum $(984,1122,1141,288,337,170,300$ and 238) (lanes 7-14). $1 \mathrm{~kb}$ ladder DNA size marker (Gibco-BRL) (lane 1). The size of diagnostic PCR product is indicated.

highly variable regions (EU068004). As predicted by the sequence analysis, the same PCR product can be obtained in L. infantum with the forward primer only (data not shown). Despite the fact that one primer is miss-annealing, the PCR reaction was fully reproducible with all tested $L$. infantum DNA templates.

In order to check the suitability of the above-described assay for differential diagnosis of clinical samples, bone marrows obtained by puncture from five infected humans and two dogs with clinical symptoms of visceral leishmaniasis were used (Table 2). We also tested a tissue sample of one person suffering from cutaneous leishmaniasis and DNA obtained from an infected Phlebotomus sp. These clinical samples were collected in 2001 and 2002 in Spain and Portugal from individuals in whom $L$. infantum was previously diagnosed using multilocus enzyme electrophoresis, with HIV co-infection detected in two cases (Campino et al. 2006). Furthermore,

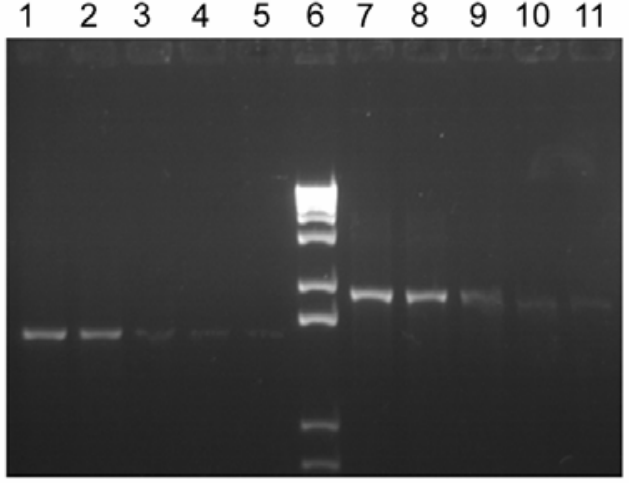

Fig. 3. Sensitivity of the assay was tested with cells of the Leishmania infantum and L. donovani strains INF-04 and DON-17, respectively. Tenfold dilutions of DNA isolated from cultured procyclics were used for PCR reactions. DNA concentrations of $L$. infantum INF-04 were 270 pg (lane 1), $135 \mathrm{pg}$ (lane 2), $67.5 \mathrm{pg}$ (lane 3), $45 \mathrm{pg}$ (lane 4) and $27 \mathrm{pg}$ (lane 5). DNA concentrations of $L$. donovani DON-17 were $9.3 \mathrm{ng}$ (lane 7), $930 \mathrm{pg}$ (lane 8), $186 \mathrm{pg}$ (lane 9), $93 \mathrm{pg}$ (lane $10)$ and $62 \mathrm{pg}$ (lane 11). $1 \mathrm{~kb}$ ladder DNA size marker (GibcoBRL) (lane 6).

bone marrow samples of eight individuals were collected by volunteers in 2002 in the rural Siraha district on the border between Nepal and India. All patients had clinical symptoms of kala-azar and were thus presumably infected by L. donovani (Regmi S., Southern Methodist University, Dallas, USA, pers. comm.). All human and canine samples were diagnosed by microscopy of Giemsa-stained smears (Campino L., Institute of Hygiene and Tropical Medicine, Lisbon, Portugal; Chicharro C., National Centre for Microbiology, Majadahonda, Spain; pers. comm.). DNA from drops of bone marrow tap from the filter papers or smeared material scrapped off the slides was isolated using $250 \mu \mathrm{l}$ of lysis buffer $(50 \mathrm{mM} \mathrm{NaCl}$; $10 \mathrm{mM}$ EDTA; $50 \mathrm{mM}$ Tris-HCl, $\mathrm{pH} 7.4 ; 1 \% \mathrm{v} / \mathrm{v}$ Triton X$100 ; 200 \mu \mathrm{g} / \mathrm{ml}$ proteinase $\mathrm{K}$ ) at $60^{\circ} \mathrm{C}$ and than extracted by phenol-chloroform extraction as described elsewhere (Maslov et al. 1996). The integrity of extracted DNA was checked by PCR with primers for the human housekeeping $\beta$-actin gene (data not shown). Next, PCR assay for the presence of Leishmania spp. DNA based on the internal transcribed spacer 1 (Schönian et al. 2003) was used to evaluate all clinical samples (data not shown). Several samples of randomly selected German and Czech blood donors, who have never visited countries endemic for leishmaniasis, were used as negative controls. The PCR assay was sensitive enough to detect either species in all tested human, canine and phlebotomine samples (Figs. 1, 2). When 10-fold dilutions of DNA from promastigotes of the L. infantum strain INF-04 and $L$. donovani strain DON-17 were used, the amplicon was obtained from less than $20 \mathrm{pg}$ and $60 \mathrm{pg}$ of Leishmania DNA, respectively (Fig. 3).

When compared with related trypanosomes, members of the genus Leishmania exhibit generally low genetic diversity and inter-specific differences are usually confined to single nucleotide polymorphisms, more or less evenly dispersed throughout the coding and non-coding regions (Mauricio et al. 2006, Lukeš et al. 2007). From the alignment it is apparent that the intergenic region in question belongs to highly variable regions of the Leishmania genome, yet the sequence remains species-specific, as exemplified by six sequences 
from three species (data not shown). Multilocus enzyme electrophoresis of a number of strains from the Sudan indicated that $L$. infantum and $L$. archibaldi co-exist with $L$. donovani in this region (Pratlong et al. 2001). However, re-examination of these strains by sequencing a dozen of protein-coding genes (Mauricio et al. 2006, Zemanová et al. 2007) and other molecular markers revealed that all Sudanese strains are monophyletic and shall be considered $L$. donovani (Lukeš et al. 2007). The capacity of this assay to affiliate these strains with $L$. donovani in accordance with the large-scale multifactorial analysis, and to distinguish between the $L$. donovani and $L$. infantum strains originating from geographically distant location, shows its strength.

We have demonstrated here that the highly variable intergenic region can be used as a diagnostic tool that enables distinction between two of the medically important Leishmania species in a single PCR reaction. Thanks to its simplicity and reliability, it is applicable for both clinical diagnostics and epidemiological studies. Moreover, since the speciesspecific amplicons are derived from the same region, this assay has a potential to be optimized for an oligochromatography-based diagnostic kit.

We thank Sandesh Regmi, Lenea Campino and Carmen Chicharro for providing clinical material, and Isabel Mauricio, Francine Pratlong, Gabi Schönian, Izrael Cruz Matta and Ketty Soteriadou for providing cell cultures and/or DNA samples of different Leishmania strains used in this study. This work was supported by grants from the Ministry of Education, Youth and Sports of the Czech Republic (2B06129 and LC 07032).

\section{References}

Botilde Y., LaUREnT T., QuisPe-Tintaya W., Chicharro C., Canavate C., CruZ I., Kuhls K., SchÖNIAN G., DuJardiN J.C. 2006: Comparison of molecular markers for strain typing of Leishmania infantum. Infect. Genet. Evol. 6: 440-446.

CAMPino L., Pratlong F., ABRANChes P., RiouX J.A., SANTOSGomes G., Alves-Pires C., Cortes S., Ramada J., CRisTOVAO J.M., AFONSO M.O., DEDET J.P. 2006: Leishmaniasis in Portugal: enzyme polymorphism of Leishmania infantum based on the identification of 213 strains. Trop. Med. Int. Health 11: 1708-1714.

CAstilho T.M., Shaw J.J., Floeter-Winter L.M. 2003: New PCR assay using glucose-6-phosphate dehydrogenase for identification of Leishmania species. J. Clin. Microbiol. 41: 540-546.

DESJEUX P. 2004: Leishmaniasis: current situation and new perspectives. Comp. Immunol. Microbiol. Infect. Dis. 27: $305-$ 318.

Dujardin J.C., Victor K., De DONCKer S., Guerbouj S., AREVAlo J., LE RAY D. 2002: Molecular epidemiology and diagnosis of Leishmania: what have we learnt from genome structure, dynamics and function? Trans. R. Soc. Trop. Med. Hyg. 96: S1-S8.

El Tai N.O., El Fari M., MaURicio I.L., Miles M.A., OSKam L., El Safi S.H., Presber W.H., SchÖNian G. 2001:
Leishmania donovani: intraspecific polymorphism of Sudanese isolates revealed by PCR-based analyses and DNA sequencing. Exp. Parasitol. 97: 35-44.

IVENS A.C., PEACOCK C.S., WORTHEY E.A., MuRPhy L., AGGARWAL G., et al. 2005: The genome of the kinetoplastid parasite, Leishmania major. Science 309: 436-442.

JiRkU゚ M., ZEMANOVÁ E., Al-JaWABReH A., SchÖNIAN G., LUKEŠ J. 2006: Development of a direct species-specific PCR assay for differential diagnosis of Leishmania tropica. Diagn. Microbiol. Infect. Dis. 55: 75-79.

LUKEŠ J., MAURICIO I.L., SCHÖNIAN G., DUJARdin J.C., SOTERiadou K., DEDET J.P., Kuhls K., QuisPe-Tintaya W., JirkŮ M., Chocholová E., Haralambous C., Pratlong F., OBORNíK M., HorÁK A., AYAla F.J., Miles M.A. 2007: Evolutionary and geographical history of the Leishmania donovani complex established by multifactorial genetic analysis. A revision of current taxonomy. Proc. Natl. Acad. Sci. USA 104: 9375-9380.

MARFURT J., NASEREDDIN A., NIEDERWIESER I., JAFFE C.L., BECK H.P., FELGER I. 2003: Identification and differentiation of Leishmania species in clinical samples by PCR amplification of the miniexon sequence and subsequent restriction fragment length polymorphism analysis. J. Clin. Microbiol. 41: 3147-3153.

MASLOV D.A., LUKEŠ J., JIRKŮ M., SIMPSON L. 1996: Phylogeny of trypanosomes as inferred from the small and large subunit rRNAs: implications for the evolution of parasitism in the trypanosomatid protozoa. Mol. Biochem. Parasitol. 75: 197205.

Mauricio I.L., Yeo M., Baghaei M., Doto D., Silk R., PratLONG F., ZEMANOVÁ E., DEDET J.P., LUKEŠ J., MILES M.A. 2006: Towards multilocus sequence typing of the Leishmania donovani complex: resolving genotypes and haplotypes for five polymorphic metabolic enzymes (ASAT, GPI, NH1, NH2, PGD). Int. J. Parasitol. 36: 757-769.

Noyes H.A., Reyburn H., Bailey J.W., SMith D. 1998: A nested PCR-based schizodeme method for identifying Leishmania kinetoplast minicircle classes directly from clinical samples and its application to the study of the epidemiology of Leishmania tropica in Pakistan. J. Clin. Microbiol. 36: 2877-2881.

Pratlong F., Dereure J., Bucheton B., El Safi S., Dessein A., LANOTTE G., DedET J.P. 2001: Sudan: the possible original focus of visceral leishmaniasis. Parasitology 122: 599605.

SCHÖNIAN G., NASEREdDIN A., DinSE N., SCHWEYNOCH C., Schallig H.D.F.H., Presber W., JafFe C.L. 2003: PCR diagnosis and characterization of Leishmania in local and imported clinical samples. Diagn. Microbiol. Infect. Dis. 47: 349-358.

ZemanovÁ E., JiRKŮ M., MAURicio I.L., HorÁK A., Miles M.A. LUKEŠ J. 2007: The Leishmania donovani complex: genotypes of five metabolic enzymes (ICD, ME, MPI, G6PDH, and $\mathrm{FH}$ ), new targets for multilocus sequence typing. Int. J. Parasitol. 37: 149-160.

Received 24 July 2007

Accepted 3 October 2007 